\title{
Recent advances reveal IL-8 signaling as a potential key to targeting breast cancer stem cells
}

\author{
Jagdeep K Singh', Bruno M Simões', Sacha J Howell, ${ }^{1,2}$ Gillian Farnie ${ }^{3}$ and Robert B Clarke*1
}

\begin{abstract}
Breast cancer stem-like cells (CSCS) are an important therapeutic target as they are purported to be responsible for tumor initiation, maintenance, metastases, and disease recurrence. Interleukin-8 (IL-8) is upregulated in breast cancer compared with normal breast tissue and is associated with poor prognosis. IL-8 is reported to promote breast cancer progression by increasing cell invasion, angiogenesis, and metastases and is upregulated in HER2-positive cancers. Recently, we and others have established that IL-8 via its cognate receptors, CXCR1 and CXCR2, is also involved in regulating breast CSC activity. Our work demonstrates that in metastatic breast CSCS, CXCR1/2 signals via transactivation of HER2. Given the importance of HER2 in breast cancer and in regulating CSC activity, a pathway driving the activation of these receptors would have important biological and clinical consequences, especially in tumors that express high levels of IL-8 and other CXCR1/2-activating ligands. Here, we review the IL-8 signaling pathway and the role of HER2 in maintaining an IL-8 inflammatory loop and discuss the potential of combining CXCR1/2 inhibitors with other treatments such as HER2-targeted therapy as a novel approach to eliminate CSCs and improve patient survival.
\end{abstract}

\section{Introduction}

The cancer stem cell model of carcinogenesis posits that cancers arise from, and are sustained by, a rare subpopulation of cells that possess stem-like characteristics [1]. Akin to normal tissue, cancer tissue is proposed to be organized in a hierarchical manner, which may underpin the cellular heterogeneity of cancers. At the apex lies the

*Correspondence: rclarke@picr.man.ac.uk

'Breast Biology, Institute of Cancer Sciences, University of Manchester, Paterson

Building, Wilmslow Road, Manchester, M20 4BX, UK

Full list of author information is available at the end of the article tumor-initiating or cancer stem-like cell (CSC), so called because these cells share key stem cell properties of their normal tissue counterparts [1]. CSCs have the capacity to self-renew and differentiate, but the mechanisms that strictly regulate these processes under normal conditions are deregulated, leading to their expansion and production of aberrantly differentiated progeny [2].

CSCs are defined functionally by their capacity to initiate a human tumor in immunocompromised mice and to self-renew, giving rise to a new tumor when passaged into another mouse, and their ability to differentiate into non-self-renewing cells which constitute the bulk of the tumor [3]. Breast cancer was the first solid tumor in which CSCs were identified [4]. By sorting cells derived from metastatic pleural effusions, Al-Hajj and colleagues demonstrated that cells expressing high levels of CD44 but low or absent CD24 and lineage markers $\left(\mathrm{CD} 44^{+} / \mathrm{CD} 24^{- \text {llow }} / \mathrm{Lin}^{-}\right)$were highly enriched for tumor-forming capacity in non-obese diabetic/severe combined immunodeficient mice. Other cell surface markers such as CD133 and CD49f and intracellular cytokeratin 5 and ALDH1 (aldehyde dehydrogenase)/ ALDEFLUOR have subsequently been used to enrich for or identify human breast CSCs [5-8]. This subpopulation of cells is also characterized by their capacity to survive in anchorage-independent conditions and be cultivated in vitro as mammospheres $[9,10]$.

There is evidence that breast CSCs are relatively resistant to chemo-, radio-, and endocrine therapies $[6,11,12]$. By evading the effects of these treatments, CSCs can survive to repopulate the tumor, leading to disease recurrence. Hence, to halt disease progression, there is a need to develop novel CSC-targeted therapies. Multiple intrinsic factors - such as drug efflux, more efficient DNA repair mechanisms, masking of receptors, quiescence, inactivation of phosphatase and tensin homolog (PTEN), and overexpression of HER2 - are reported to confer resistance of breast CSCs to conventional therapies.

Accumulating evidence indicates that extrinsic factors and other cells that form part of the tumor microenvironment and CSC niche are also responsible for regulating and promoting CSC activity. The association between 
inflammation and cancer is well established, and deregulated expression of multiple inflammatory cytokines, including interleukin-8 (IL-8), in malignant breast disease has been recognized for more than 15 years. Although there is substantial evidence that IL-8 is increased in breast cancer, the mechanisms by which IL-8 contributes to breast cancer progression have remained virtually unknown. However, recent studies indicate that IL-8 can promote CSC invasion, metastases, and treatment resistance. Targeting CXCR1/2 signaling has proven efficacious in in vivo models of breast cancer as well as primary invasive and metastatic breast cancers, catalyzing the initiation of clinical trials evaluating CXCR1/2 inhibitors. Here, we review the key components of the IL-8 signaling pathway, evidence implicating IL-8 in breast cancer, regulation of CSC activity via CXCR1/2, and the role of HER2 in maintaining an IL-8 inflammatory loop and discuss the potential of combining CXCR1/2 inhibitors with other treatments to improve outcomes in breast cancer.

\section{The IL-8 signaling pathway}

IL-8, also known as C-X-C motif ligand (CXCL) 8 (CXCL8), is a small soluble protein and belongs to the CXC chemokine family, which is one of four chemokine families [13]. The CXC family is characterized by a single amino acid, named ' $\mathrm{X}$ ', between the first two cysteines and is derived from a gene cluster mapped to chromosome 4 between q12 and q21 [14]. IL-8 was originally identified as a potent neutrophil activator and chemotactic factor secreted by activated monocytes and macrophages [15-17]. Many other cell types - including fibroblasts [18], lymphocytes [19], neutrophils [20], endothelial cells [21], and a variety of normal and malignant epithelial cells [22-27] - have since been shown to secrete IL-8. IL-8 is pro-angiogenic and this property is conferred by a Glu-Leu-Arg motif that precedes the first $\mathrm{N}$-terminal cysteine residue [28,29].

The biological effects of IL-8 are mediated via two class A, rhodopsin-like guanine-protein-coupled receptors (GPCRs): CXCR1 (IL-8RA) and CXCR2 (IL-8RB) [30,31]. The genes encoding CXCR1 and CXCR2 are located in close proximity to each other on chromosome 2 (2q34-35) [32]. The CXCR1 gene consists of two exons separated by an intron [33], whereas CXCR2 consists of three exons separated by two introns [34]. The receptors share $77 \%$ amino acid homology and retain common structural motifs, raising the possibility that they may have derived from gene duplication [31,35].

Like other GPCRs, CXCR1 and CXCR2 are characterized by 7 -transmembrane-spanning regions, an extracellular N-terminus, and an intracellular C-terminus [36]. CXCR1 is activated by IL- 8 and granulocyte chemotactic protein-2 (GCP-2)/CXCL6 [37]. CXCR2 is more promiscuous as it can be activated not only by IL- 8 but by many other CXC chemokines such as growthregulated oncogene (GRO)- $\alpha / C X C L 1$, GRO- $\beta / C X C L 2$, GRO- $\gamma /$ CXCL3, CXCL5, GCP-2, and neutrophilactivating protein-2 (NAP-2)/CXCL7 [37]. Studies in phospholipid bilayers indicate that the cell membrane is important in mediating IL- 8 binding to the N-terminal residues of CXCR1 [38]. Ligand receptor interactions are complex and exactly how these interactions mediate ligand-binding affinity and receptor activation remains largely unknown [39]. However, studies demonstrate that signaling requires interaction between the $\mathrm{N}$-terminal region of IL- 8 and the N-terminal extracellular domain of the receptors $[40,41]$.

As with other GPCRs, CXCR1 and CXCR2 are characterized by their association with heterotrimeric $\mathrm{G}$ proteins, which consist of $\alpha, \beta$, and $\gamma$ subunits [42]. Ligand binding catalyzes the exchange of guanosine diphosphate for guanosine triphosphate on the $\mathrm{G \alpha}$ subunit, which triggers the release of this subunit from

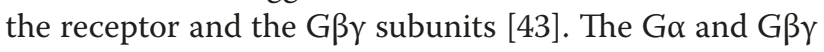
subunits subsequently activate a variety of signaling pathways that can have different effects depending on the cell type. The three principal pathways are phosphatidylinositol 3' kinase/Akt (PI3K/Akt), phospholipase C/ protein kinase $\mathrm{C}$ (PLC/PKC), and Ras/Raf/extracellular signal-regulated protein kinases 1 and 2 (Erk1/2) [44-46]. Other signaling pathways include focal adhesion kinase, Rho, Rac, and janus kinase/signal transducers and activators of transcription (JAK/STAT) [47-49].

\section{IL-8 and breast cancer}

IL-8 is upregulated in a wide variety of solid cancers, such as prostate, gastric, bladder, ovarian, lung, and melanoma, and is reported to contribute to multiple hallmarks of cancer, such as increased proliferation, angiogenesis, invasion, and metastases [25,26,50-53]. IL-8 is overexpressed in breast cancer compared with normal breast tissue, and although there is substantial evidence that IL- 8 may promote breast cancer initiation and progression via the above mechanisms, more recent evidence indicates that this cytokine is a key regulator of CSC activity. Novel therapeutics aimed at inhibiting CXCR1/2 signaling may halt disease progression in tumors driven by IL- 8 and other CXCR $1 / 2$ ligands.

Breast cancer cells are reported to express CXCR $1 / 2$ [54] and secrete IL-8 [27,55], and rare genetic polymorphisms of CXCR2 and IL-8 are associated with an increased risk of developing large, high-grade, lymph node-positive breast cancers [56,57]. Regulation of IL-8 within the tumor microenvironment is complex, not only because of the variety of cells that can secrete it but also because of the multitude of factors that can affect IL-8 expression by these different cell types (Figure 1). Other 


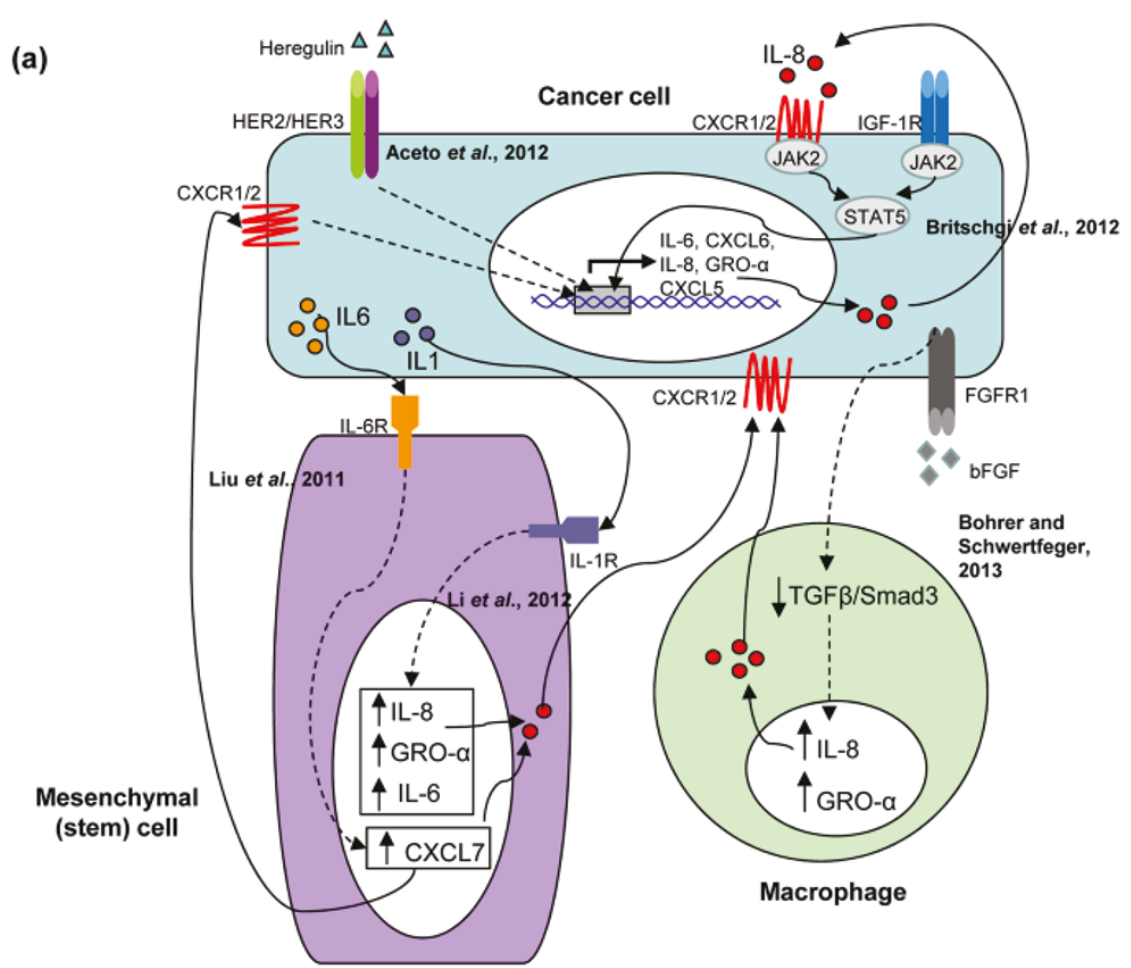

(b)

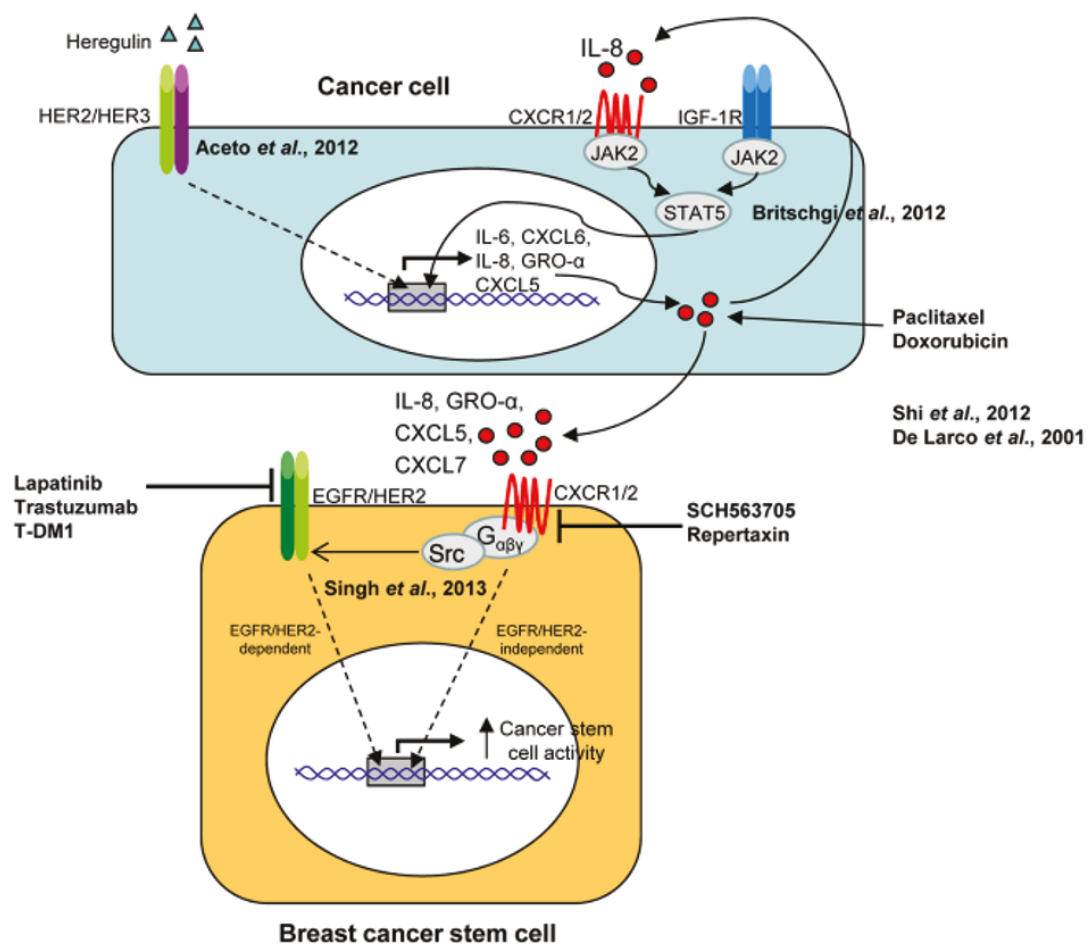

Figure 1. Model of cytokine networks depicting the proposed interactions between breast cancer cells and stromal cells. (a) Interleukin-8 (IL-8) is secreted by cancer cells, mesenchymal cells, and macrophages via multiple signaling pathways. (b) IL-8 promotes breast cancer stem-like cell (CSC) activity via CXCR1/2 by activating EGFR/HER2-dependent and -independent signaling pathways. Red circles denote CXCR1/2 ligands: IL-8/CXCL8, CXCL1/GRO-a, CXCL5, CXCL6/GCP-2, and CXCL7/NAP-2. bFGF, basic fibroblast growth factor; CXCL, C-X-C motif ligand; EGFR, epidermal growth factor receptor; FGFR, fibroblast growth factor receptor; GCP-2, granulocyte chemotactic protein-2; GRO, growth-regulated oncogene; HER2, human growth factor receptor 2; IGF-1R, insulin-like growth factor 1 receptor; JAK/STAT, Janus kinase/signal transducers and activators of transcription; NAP-2, neutrophil-activating protein-2; Src, sarcoma kinase; TGF- $\beta$, transforming growth factor-beta. 
cytokines such as IL-1 $\beta$, tumor necrosis factor-alpha, and IL-6; growth factors such as epidermal growth factor; and hormones such as estrogen and progesterone are all reported to upregulate IL-8 expression in breast cancer cells [58-60]. Recent co-culture studies indicate that activation of fibroblast growth factor receptor in mammary tumor cells induces upregulation of IL- 8 and other CXCR1/2 ligands by macrophages through decreased activity of the transforming growth factorbeta/Smad3 pathway, resulting in increased tumor cell migration and invasion [61]. Cross-talk between breast cancer cells and mesenchymal cells, which form an integral part of the tumor stroma, can also induce secretion of several CXCR1/2 ligands, including IL-8, CXCL1/GRO- $\alpha$, CXCL6/GCP-2, and CXCL7/NAP-2 [62].

In order for cells to metastasize, they must invade surrounding structures. Several studies have demonstrated a positive correlation between ectopic IL-8 expression and the invasive potential of breast cancer cells. In breast cancer cell lines, invasion is directly proportional to IL-8 expression, and overexpression or treatment with recombinant IL-8 promotes invasion $[27,63]$. Conversely, short-interfering RNA knockdown of IL-8 in breast cancer cell lines with relatively high constitutive expression, such as MDA-MB 231, inhibits invasion [64].

Further evidence implicating IL-8 in the metastatic process comes from in vivo studies. Using an in vivo selection method to generate cells with a high or low metastatic phenotype from the parental MDA-MB 231 cell line, Bendre and colleagues [65] (2002) demonstrated significant upregulation of IL-8 and invasion in the highly metastatic cells compared with the poorly metastatic cells. Furthermore, IL-8 expression in cells cultured from experimental lung metastases is substantially greater than in cells cultured from primary tumors [58]. Consistent with these findings, clinical studies report significantly higher IL-8 levels at metastatic sites compared with primary sites [66]. More recent studies demonstrate that knockdown of CXCR2 or inhibition of CXCR1/2 activity decreases spontaneous metastases in vivo $[67,68]$. Together, these studies demonstrate that IL-8 and other CXCR1/2 ligands are important in facilitating metastatic colonization in breast cancer.

Chemo-resistance resulting in incurable disease remains a significant problem in managing patients with breast cancer, especially in the metastatic setting, in which cure is not achievable. Several mechanisms - such as drug efflux via breast cancer resistance proteins, more efficient DNA repair mechanisms, masking of receptors, and inactivation of PTEN - have been implicated in conferring this phenotype. Accumulating evidence indicates that increased activity of CXCR $1 / 2$ via ligand upregulation may serve as an adaptive response to protect cancer cells from the cytotoxic effect of conventional chemotherapy agents, thereby limiting their clinical efficacy. Certainly, patients with metastatic disease treated with multiple cycles of chemotherapy have elevated serum IL-8 levels compared with those with localized cancers [69]. Moreover, serum IL-8 level is an independent prognostic factor for post-relapse survival in patients with metastatic breast cancer [70]. In vitro upregulation of IL- 8 and other CXCR1/2 ligands by breast cancer cells is observed in response to conventional chemotherapy, and multidrug-resistant breast cancer cell lines produce significantly higher IL-8 protein levels compared with non-resistant controls $[71,72]$. Furthermore, failure of novel targeted therapies, such as $\mathrm{PI} 3 \mathrm{~K} / \mathrm{mammalian}$ target of rapamycin (mTOR) inhibitors, has been attributed to upregulation of IL-8 via alternative signaling pathways involving JAK2/STAT5 [49].

Pharmacological inhibition or genetic knockdown of IL-8, however, has been shown to sensitize breast cancer cells to the cytotoxic effects of conventional chemotherapy agents [71]. Importantly, in human breast cancer xenograft models, CXCR1 inhibition is reported to add to the efficacy of docetaxel, resulting in greater inhibition of tumor growth and reduction in systemic metastases [68]. Given these promising results, combining CXCR1/2 inhibitors with standard chemotherapy agents and emerging targeted therapies, which may directly or indirectly increase IL-8 as part of the adaptive response, could help to overcome treatment resistance, resulting in improved outcomes.

\section{Regulation of breast cancer stem cell activity via CXCR1/2}

The failure of current therapies to eradicate breast cancer is hypothesized to be due to the existence of a subpopulation of cells that can evade the effects of these treatments. Substantial evidence indicates that breast CSCs are intrinsically resistant to chemo-, radio-, and endocrine therapies and, as such, can survive to repopulate the tumor, resulting in disease recurrence. It is becoming evident that, in addition to intrinsic resistance mechanisms, complex cytokine networks within the tumor microenvironment can rescue and promote CSC activity while more differentiated cells within the tumor succumb to the effects of conventional therapies. Recent studies indicate that CXCR1/2 signaling forms an important defense mechanism in regulating breast CSC activity. CXCR1 is overexpressed in the CSC subpopulation compared with bulk tumor cells, and ligand activation promotes their invasive capacity [68,73]. More recent studies indicate that IL-8 can promote a state of 'stemness' by inducing epithelial-mesenchymal transition 
[74], a process that is implicated in regulating invasion and metastasis and in the acquisition of stem cell characteristics [75-77].

Activation of CXCR1/2 in breast cancer cell lines with recombinant IL-8 is reported to expand the pool of CSCs and increase self-renewal $[62,73]$. We recently validated these findings by using a different panel of breast cancer cell lines and, importantly, found the same effect on selfrenewal in primary samples isolated both from invasive breast tumors and from metastatic cells from ascites and pleural effusions [78]. Interestingly, we demonstrated a significant direct correlation between metastatic fluid IL8 level and mammosphere formation when cells from such fluid were cultured ex vivo, suggesting that cancers with higher IL-8 levels have greater CSC activity [78].

Recent in vivo studies report that bone marrow-derived mesenchymal stem cells (MSCs) are recruited to sites of developing tumors, co-localize with breast CSCs within the CSC niche, and are responsible for accelerating tumor growth by increasing the population of breast CSCs through cytokine networks [62]. Mechanistically, Liu and colleagues [62] propose that these effects are initiated by cancer cell-derived IL- 6 and sustained by IL- 8 and other CXCR1/2 ligands, namely CXCL6/GCP-2 and CXCL7/ NAP-2, released from both the cancer cells and mesenchymal cells. Furthermore, cancer cell-derived IL-1 can induce expression of IL- 8 and CXCL1/GRO- $\alpha$ by MSCs, thereby contributing to the formation and maintenance of CSCs [79].

A recent study reports coordinated regulation of IL-8 with IL-6 and CXCL1/GRO- $\alpha$ in triple-negative breast cancers (TNBCs) which may contribute to the poor prognosis of this subgroup [80]. In that study, Hartman and colleagues demonstrated that stimulation of TNBC cells with lysophosphatidic acid (LPA), an inducer of inflammatory signaling, resulted in coordinated secretion of IL-8, IL-6, and CXCL1/GRO- $\alpha$ via an EZH2/nuclear factor $\kappa$-light-chain-enhancer of activated B cells $(\mathrm{NF} \kappa \mathrm{B})$ dependent pathway. These effects were abrogated by pharmacological or genetic inhibition of the LPA receptor, EZH2 (a critical regulator of NFKB-induced inflammatory gene expression), or direct inhibition of NFKB [80].

Inhibition of CXCR1/2 signaling by using repertaxin, a non-competitive inhibitor, is reported to decrease the proportion and activity of CSCs in vitro, as measured by a decrease in the fraction of ALDEFLUOR-positive cells and mammosphere formation, respectively [68]. In vivo, treatment of mouse xenografts with repertaxin decreased tumor growth and increased the efficacy of docetaxel. This was associated with a reduction in the tumorinitiating and self-renewal properties of the remaining CSCs as demonstrated by a reduction of tumor formation following re-implantation of cells into recipient mice
[68]. More recently, Hartman and colleagues [80] (2013) reported similar effects on anchorage-independent colony formation in TNBC cells by using short-hairpin RNA (shRNA) to knock down IL-8 and CXCR1. Moreover, concurrent inhibition of IL- 8 and IL-6 had a synergistic effect on reducing colony formation and tumor initiation in vivo as well as increasing apoptosis and sensitizing cells to paclitaxel [80]. Together, the above studies demonstrate that the CXCR $1 / 2$ signaling axis forms an integral component of a complex inflammatory cytokine response which is critical in maintaining breast CSC activity via autocrine or paracrine routes or both.

\section{IL-8 inflammatory feedback loop in breast cancer: the role of HER2}

Up to $25 \%$ of breast cancers overexpress HER2, conferring a higher rate of recurrence and mortality [81]. Studies suggest that HER2 overexpression promotes tumor formation and metastasis by increasing the proportion of CSCs and their self-renewal and invasive properties [82,83]. More recently, it has been proposed that HER2 may promote breast cancer initiation and progression by activating multiple pro-inflammatory cytokine feedback loops. Overexpression of HER2 is reported to increase IL-6 expression, generating an autocrine-positive feedback loop via STAT3/Akt/NFkB signaling pathways, resulting in enhanced breast CSC activity and HER2 treatment resistance $[60,84]$. Accumulating evidence indicates that HER2 modulates IL-8, and in light of recent findings discussed below, we propose that HER2 forms an integral component of an IL-8dependent positive feedback loop leading to increased breast CSC activity. Mechanistically, this may contribute to the poor prognosis of HER2-enriched tumors.

Overexpression of HER2 in breast cancer cell lines is reported to induce a 'cytokine signature' characterized by upregulation of IL- 8 and other CXCR1/2 agonists such as CXCL1/GRO- $\alpha[85,86]$. This effect is potentiated by coexpression of HER2 and HER3 via increased autoactivation of HER2 [87]. Conversely, inhibition of HER2 activity by using pharmacological inhibitors or genetic knockdown reduces IL-8 expression in HER2-overexpressing breast cancer cell lines through inhibition of the PI3K-Akt signaling pathway $[85,86]$. In vivo, inhibition of tumor growth with trastuzumab is associated with downregulation of IL-8 in HER2-positive xenografts [85].

The correlation between HER2 overexpression and increased IL- 8 is supported by clinical evidence. A series of early small studies reported higher serum IL-8 levels in patients with metastatic HER2-positive disease compared with HER2-negative disease and higher IL-8 protein level in HER2-positive cancers compared with HER2-negative 
cancers $[86,88]$. These findings have recently been corroborated by using bioinformatic analysis of 1,881 primary breast cancer samples derived from multiple large datasets [87]. Using gene set analysis, Aceto and colleagues reported significantly higher levels of IL-8 transcripts in tumors displaying a HER2-enriched phenotype compared with normal-like and luminal subtypes.

We recently reported fresh insights into HER2 signaling in breast cancer by demonstrating transactivation of HER2 upon ligand activation of CXCR1/2 [78]. We found that transactivation of HER2 via CXCR $1 / 2$ is Srcdependent and leads to the activation of AKT and ERK1/2 signaling pathways, which are known to be critical in regulating breast CSC activity [78,89]. Inhibition of HER2 activity with lapatinib, a dual epidermal growth factor receptor (EGFR)/HER2 tyrosine kinase inhibitor, abrogated the mammosphere-promoting effect of IL-8 in both HER2-positive and -negative primary breast cancers. These findings demonstrate that the functional effects of CXCR1/2 activation are dependent, at least in part, on HER2. Importantly, in HER2-positive cancers, CXCR1/2 inhibition was found to add to the efficacy of HER2 inhibition [78]. Given the importance of HER2 in regulating CSC activity, activation of this pathway could have important biological consequences especially in tumors expressing high levels of CXCR $1 / 2$ ligands.

There is evidence that IL-8 shows an inverse association with estrogen receptor (ER) expression, with ER-negative breast cancers expressing higher levels of IL-8 compared with ER-positive cancers $[27,88]$. In light of recent evidence implicating IL-8 in driving disease progression, it is possible that elevated levels of IL-8 are responsible for selectively driving disease progression in ER-negative/ triple-negative tumors compared with ER-positive tumors; however, this remains to be determined.

Together, the above studies support the existence of an IL-8-positive feedback loop, as summarized in Figure 1. Once activated, this can initiate a self-perpetuating cycle leading to continuous stimulation of breast CSC activity and thereby hastening disease progression. Production of IL- 8 by cancer cells, mesenchymal cells, and macrophages promotes breast CSC activity via CXCR $1 / 2$ by activating EGFR/HER2-dependent and -independent signaling pathways. Direct activation or auto-activation of HER2 can increase IL-8 expression which can further activate CXCR1/2 signaling via a paracrine or autocrine route or both. Other cytokine feedback loops, such as IL-6, could potentially feed into the above cycle by upregulating IL- 8 production via NFKB signaling [60]. Transcriptional activation of $\mathrm{IL}-8$ is controlled primarily by $\mathrm{NF \kappa B}$; however, other transcription factors such as activating protein-1 and CAAT/enhancer-binding proteins can also regulate IL-8 expression and act synergistically with
$\mathrm{NF \kappa B}$ to augment gene expression [90,91]. NFkB is also responsible for regulating expression of IL-6, although more recent evidence indicates that this transcription factor is involved in regulating the coordinated expression of IL-6 and IL-8 in TNBCs. Mechanistically, this may be responsible for conferring the synergistic effect of these cytokines in regulating breast CSC activity and contribute to the poor prognosis of this subtype [80]. Thus, dual inhibition of IL- 6 and IL- 8 or inhibition of $\mathrm{NF} \kappa \mathrm{B}$ may be required to derive therapeutic benefit in tumors in which cytokine expression is coordinated.

\section{Targeting CXCR1/2 signaling in breast cancer}

Increasing evidence indicates that IL-8 is a key extrinsic regulator of breast CSC activity. This may contribute to the poorer prognosis of tumors that express high levels of IL-8 or other CXCR1/2 ligands and contribute to treatment resistance. Consequently, targeting CXCR1/2 signaling may abrogate disease progression in a subset of breast cancers. Pharmacologically, this can be approached by interfering with either ligand activation or receptor function. Antibodies against IL-8 have demonstrated anti-tumor effects in xenograft models of bladder cancer [92] and melanoma [93]. Trials in patients with chronic inflammatory diseases associated with increased production of IL-8, such as palmoplantar pustulosis, report that monoclonal humanized antibodies to IL-8 are clinically effective and well tolerated [94]. Although IL-8 is the most well-studied CXCR1/2 ligand in breast cancer, targeting IL-8 alone may be of limited benefit since other CXCR1/2 agonists - such as CXCL1/GRO- $\alpha$, CXCL2/ GRO- $\beta$ CXCL3/GRO- $\gamma$, and CXCL5 - are co-regulated with IL-8 [66]. This problem can be circumvented by inhibiting CXCR1/2.

Various orally active small-molecule non-competitive antagonists of CXCR1 and CXCR2 - such as repertaxin (Dompé, Milan, Italy), SCH479833 (Merck, Whitehouse Station, NJ, USA), and SCH527123 (Merck) - have demonstrated anti-tumor effects in xenograft models of breast cancer [68], colorectal cancer [95], and melanoma [52], including the inhibition of spontaneous colon cancer liver metastasis [96]. SCH563705 (Merck) has demonstrated particularly high binding affinities to CXCR1 and CXCR2 and has proven effective at inhibiting primary human breast CSC activity [78].

Owing to the pleiotropic effects of IL-8, caution must be exercised when trialling CXCR $1 / 2$ inhibitors as they could have unexpected toxicities. In addition to promoting tumorigenesis by increasing angiogenesis and invasion, IL-8 is reported to exert anti-tumor effects through neutrophil recruitment [97]. Neutrophils and other cells such as cytotoxic $\mathrm{T}$ cells, $\mathrm{T}$ helper cells, and natural killer cells form part of the immune surveillance system which operates to detect and eradicate cancer cells [98]. Hence, 
CXCR1/2 inhibitors could inadvertently promote tumor growth by blocking the anti-tumor effects of neutrophil infiltration. Novel technologies aimed at delivering drugs specifically to the cancer cells could help minimize these effects. Similarly, CXCR1/2 inhibitors have been shown to reduce circulating neutrophil counts with the potential for synergistic myelo-toxicity when combined with chemotherapeutic agents [99].

Although the above CXCR1/2 inhibitors have shown efficacy in preclinical studies, they are still in the early stages of drug development. Repertaxin, originally developed to prevent IL-8-induced reperfusion injury, is the only CXCR $1 / 2$ inhibitor that has undergone clinical testing [100]. Phase I trials demonstrate that repertaxin [101] and SCH527123 [99] are well tolerated in healthy volunteers and patients with severe asthma, respectively. Based on recent evidence that CXCR1/2 inhibition can inhibit breast CSC self-renewal and metastases in vivo [68], clinical trials are under way to determine the safety and efficacy of repertaxin in combination with docetaxel chemotherapy in patients with advanced breast cancer [102-104].

\section{Conclusions}

Ultimately, combining CXCR $1 / 2$ inhibitors with existing chemotherapy and endocrine therapy agents or HER2targeted therapies (or both) may be more effective at eliminating both the CSC and non-CSC populations, leading to improved outcomes in both the adjuvant and advanced settings.

\section{Abbreviations}

CSC, cancer stem-like cell; CXCL, C-X-C motif ligand; EGFR, epidermal growth factor receptor; ER, estrogen receptor; ERK1/2, extracellular signal-regulated protein kinase 1 and 2; GCP-2, granulocyte chemotactic protein-2; GPCR, guanine-protein-coupled receptor; GRO, growth-regulated oncogene; HER2, human growth factor receptor 2; IL, interleukin; JAK/STAT, Janus kinase/ signal transducers and activators of transcription; LPA, lysophosphatidic acid; MSC, mesenchymal stem cell; NAP-2, neutrophil-activating protein-2; NFKB, nuclear factor kappa-light-chain-enhancer of activated B cells; PI3K, phosphatidylinositol 3'kinase; PTEN, phosphatase and tensin homolog; TNBC, triple-negative breast cancer.

\section{Competing interests}

The authors declare that they have no competing interests.

\section{Author details}

'Breast Biology, Institute of Cancer Sciences, University of Manchester, Paterson Building, Wilmslow Road, Manchester, M20 4BX, UK. '2Department of Medical Oncology, The Christie NHS Foundation Trust, Wilmslow Road, Manchester, M20 4BX, UK. ${ }^{3}$ Cancer Stem Cell Research, Institute of Cancer Sciences, University of Manchester, Paterson Building, Wilmslow Road, Manchester, M20 4BX, UK.

Published: 30 August 2013

\section{References}

1. Polyak K, Hahn WC: Roots and stems: stem cells in cancer. Nat Med 2006, 12:296-300.

2. Wicha MS, Liu S, Dontu G: Cancer stem cells: an old idea - a paradigm shift. Cancer Res 2006, 66:1883-1890; discussion 1895-1886.

3. McDermott SP, Wicha MS: Targeting breast cancer stem cells. Mol Oncol 2010,
4:404-419

4. Al-Hajj M, Wicha MS, Benito-Hernandez A, Morrison SJ, Clarke MF: Prospective identification of tumorigenic breast cancer cells. Proc Natl Acad Sci U S A 2003, 100:3983-3988.

5. Ginestier C, Hur MH, Charafe-Jauffret E, Monville F, Dutcher J, Brown M, Jacquemier J, Viens P, Kleer CG, Liu S, Schott A, Hayes D, Birnbaum D, Wicha MS, Dontu G: ALDH1 is a marker of normal and malignant human mammary stem cells and a predictor of poor clinical outcome. Cell Stem Cell 2007, 1:555-567.

6. Kabos P, Haughian JM, Wang X, Dye WW, Finlayson C, Elias A, Horwitz KB, Sartorius CA: Cytokeratin 5 positive cells represent a steroid receptor negative and therapy resistant subpopulation in luminal breast cancers. Breast Cancer Res Treat 2010, 128:45-55.

7. Meyer MJ, Fleming JM, Lin AF, Hussnain SA, Ginsburg E, Vonderhaar BK: CD44posCD49fhiCD133/2hi defines xenograft-initiating cells in estrogen receptor-negative breast cancer. Cancer Res 2010, 70:4624-4633.

8. Wright MH, Calcagno AM, Salcido CD, Carlson MD, Ambudkar SV, Varticovski L: Brca1 breast tumors contain distinct CD44+/CD24- and CD133+ cells with cancer stem cell characteristics. Breast Cancer Res 2008, 10:R10.

9. Dontu G, Abdallah WM, Foley JM, Jackson KW, Clarke MF, Kawamura MJ, Wicha MS: In vitro propagation and transcriptional profiling of human mammary stem/progenitor cells. Genes Dev 2003, 17:1253-1270.

10. Ponti D, Costa A, Zaffaroni N, Pratesi G, Petrangolini G, Coradini D, Pilotti S, Pierotti MA, Daidone MG: Isolation and in vitro propagation of tumorigenic breast cancer cells with stem/progenitor cell properties. Cancer Res 2005, 65:5506-5511.

11. Li X, Lewis MT, Huang J, Gutierrez C, Osborne CK, Wu MF, Hilsenbeck SG, Pavlick A, Zhang X, Chamness GC, Wong H, Rosen J, Chang JC: Intrinsic resistance of tumorigenic breast cancer cells to chemotherapy. J Natl Cancer Inst 2008, 100:672-679

12. Diehn M, Cho RW, Lobo NA, Kalisky T, Dorie MJ, Kulp AN, Qian D, Lam JS, Ailles LE, Wong M, Joshua B, Kaplan MJ, Wapnir I, Dirbas FM, Somlo G, Garberoglio C, Paz B, Shen J, Lau SK, Quake SR, Brown JM, Weissman IL, Clarke MF: Association of reactive oxygen species levels and radioresistance in cancer stem cells. Nature 2009, 458:780-783.

13. Rossi D, Zlotnik A: The biology of chemokines and their receptors. Annu Rev Immunol 2000, 18:217-242.

14. Modi WS, Dean M, Seuanez HN, Mukaida N, Matsushima K, O'Brien SJ: Monocyte-derived neutrophil chemotactic factor (MDNCF/L-8) resides in a gene cluster along with several other members of the platelet factor 4 gene superfamily. Hum Genet 1990, 84:185-187.

15. Walz A, Peveri P, Aschauer $H$, Baggiolini M: Purification and amino acid sequencing of NAF, a novel neutrophil-activating factor produced by monocytes. Biochem Biophys Res Commun 1987, 149:755-761.

16. Schroder JM, Mrowietz U, Morita E, Christophers E: Purification and partial biochemical characterization of a human monocyte-derived, neutrophilactivating peptide that lacks interleukin 1 activity. J Immuno/ 1987, 139:3474-3483.

17. Yoshimura T, Matsushima K, Tanaka S, Robinson EA, Appella E, Oppenheim JJ, Leonard EJ: Purification of a human monocyte-derived neutrophil chemotactic factor that has peptide sequence similarity to other host defense cytokines. Proc Natl Acad Sci U S A 1987, 84:9233-9237.

18. Schroder JM, Sticherling M, Henneicke HH, Preissner WC, Christophers E: IL-1 alpha or tumor necrosis factor-alpha stimulate release of three NAP-1/ IL-8-related neutrophil chemotactic proteins in human dermal fibroblasts. $J$ Immunol 1990, 144:2223-2232

19. Gregory H, Young J, Schroder JM, Mrowietz U, Christophers E: Structure determination of a human lymphocyte derived neutrophil activating peptide (LYNAP). Biochem Biophys Res Commun 1988, 151:883-890

20. Bazzoni F, Cassatella MA, Rossi F, Ceska M, Dewald B, Baggiolini M: Phagocytosing neutrophils produce and release high amounts of the neutrophil-activating peptide 1/interleukin 8. J Exp Med 1991, 173:771-774.

21. Gimbrone MA Jr., Obin MS, Brock AF, Luis EA, Hass PE, Hébert CA, Yip YK, Leung DW, Lowe DG, Kohr WJ, Darbonne WC, Bechtol KB, Baker JB: Endothelial interleukin-8: a novel inhibitor of leukocyte-endothelial interactions. Science 1989, 246:1601-1603.

22. Elner VM, Strieter RM, Elner SG, Baggiolini M, Lindley I, Kunkel SL: Neutrophil chemotactic factor (IL-8) gene expression by cytokine-treated retinal pigment epithelial cells. Am J Pathol 1990, 136:745-750.

23. Standiford TJ, Kunkel SL, Basha MA, Chensue SW, Lynch JP 3rd, Toews GB, Westwick J, Strieter RM: Interleukin-8 gene expression by a pulmonary 
epithelial cell line. A model for cytokine networks in the lung. J Clin Invest 1990, 86:1945-1953.

24. Kitadai Y, Haruma K, Sumii K, Yamamoto S, Ue T, Yokozaki H, Yasui W, Ohmoto Y, Kajiyama G, Fidler IJ, Tahara E: Expression of interleukin-8 correlates with vascularity in human gastric carcinomas. Am J Pathol 1998, 152:93-100.

25. Venkatakrishnan G, Salgia R, Groopman JE: Chemokine receptors CXCR-1/2 activate mitogen-activated protein kinase via the epidermal growth factor receptor in ovarian cancer cells. J Biol Chem 2000, 275:6868-6875.

26. Inoue K, Slaton JW, Kim SJ, Perrotte P, Eve BY, Bar-Eli M, Radinsky R, Dinney CP: Interleukin 8 expression regulates tumorigenicity and metastasis in human bladder cancer. Cancer Res 2000, 60:2290-2299.

27. Freund A, Chauveau C, Brouillet J-P, Lucas A, Lacroix M, Licznar A, Vignon F, Lazennec G: IL-8 expression and its possible relationship with estrogenreceptor-negative status of breast cancer cells. Oncogene 2003, 22:256-265.

28. Koch AE, Polverini PJ, Kunkel SL, Harlow LA, DiPietro LA, Elner VM, Elner SG, Strieter RM: Interleukin-8 as a macrophage-derived mediator of angiogenesis. Science 1992, 258:1798-1801.

29. Strieter RM, Polverini PJ, Kunkel SL, Arenberg DA, Burdick MD, Kasper J, Dzuiba J, Van Damme J, Walz A, Marriott D, Chan S, Roczniak S, Shanafelt AB: The functional role of the ELR motif in CXC chemokine-mediated angiogenesis. J Biol Chem 1995, 270:27348-27357.

30. Holmes WE, Lee J, Kuang WJ, Rice GC, Wood WI: Structure and functional expression of a human interleukin-8 receptor. Science 1991, 253:1278-1280.

31. Murphy PM, Tiffany HL: Cloning of complementary DNA encoding a functional human interleukin-8 receptor. Science 1991, 253:1280-1283.

32. Lloyd A, Modi W, Sprenger H, Cevario S, Oppenheim J, Kelvin D: Assignment of genes for interleukin-8 receptors (IL8R) A and B to human chromosome band 2q35. Cytogenet Cell Genet 1993, 63:238-240.

33. Sprenger H, Lloyd AR, Meyer RG, Johnston JA, Kelvin DJ: Genomic structure, characterization, and identification of the promoter of the human IL-8 receptor A gene. J Immunol 1994, 153:2524-2532.

34. Sprenger H, Lloyd AR, Lautens LL, Bonner TI, Kelvin DJ: Structure, genomic organization, and expression of the human interleukin-8 receptor B gene. $J$ Biol Chem 1994, 269:1 1065-11072.

35. Ahuja SK, OzcelikT, Milatovitch A, Francke U, Murphy PM: Molecular evolution of the human interleukin-8 receptor gene cluster. Nat Genet 1992, 2:31-36.

36. Kobilka BK: G protein coupled receptor structure and activation. Biochim Biophys Acta 2007, 1768:794-807.

37. Ahuja SK, Murphy PM: The CXC chemokines growth-regulated oncogene (GRO) alpha, GRObeta, GROgamma, neutrophil-activating peptide-2, and epithelial cell-derived neutrophil-activating peptide-78 are potent agonists for the type $B$, but not the type $A$, human interleukin- 8 receptor. J Biol Chem 1996, 271:20545-20550.

38. Park SH, Casagrande F, Cho L, Albrecht L, Opella SJ: Interactions of interleukin- 8 with the human chemokine receptor CXCR1 in phospholipid bilayers by NMR spectroscopy. J Mol Bio/ 2011, 414:194-203.

39. Rajagopalan L, Rajarathnam K: Ligand selectivity and affinity of chemokine receptor CXCR1. Role of N-terminal domain. J Biol Chem 2004, 279:30000-30008,

40. Clark-Lewis I, Schumacher C, Baggiolini M, Moser B: Structure-activity relationships of interleukin-8 determined using chemically synthesized analogs. Critical role of $\mathrm{NH}$ 2-terminal residues and evidence for uncoupling of neutrophil chemotaxis, exocytosis, and receptor binding activities. J Biol Chem 1991, 266:23128-23134.

41. Clark-Lewis I, Dewald B, Loetscher M, Moser B, Baggiolini M: Structural requirements for interleukin-8 function identified by design of analogs and CXC chemokine hybrids. J Bio/ Chem 1994, 269:16075-16081.

42. Waugh DJ, Wilson C: The interleukin-8 pathway in cancer. Clin Cancer Res 2008, 14:6735-6741.

43. Stillie R, Farooq SM, Gordon JR, Stadnyk AW: The functional significance behind expressing two IL-8 receptor types on PMN. J Leukoc Bio/ 2009, 86:529-543.

44. Wu D, LaRosa GJ, Simon Ml: G protein-coupled signal transduction pathways for interleukin-8. Science 1993, 261:101-103.

45. Knall C, Young S, Nick JA, Buhl AM, Worthen GS, Johnson GL: Interleukin-8 regulation of the Ras/Raf/mitogen-activated protein kinase pathway in human neutrophils. J Biol Chem 1996, 271:2832-2838.

46. Knall C, Worthen GS, Johnson GL: Interleukin 8-stimulated phosphatidylinositol-3-kinase activity regulates the migration of human neutrophils independent of extracellular signal-regulated kinase and p38 mitogen-activated protein kinases. Proc Natl Acad Sci U S A 1997, 94:3052-3057.
47. Cohen-Hillel E, Yron I, Meshel T, Soria G, Attal H, Ben-Baruch A: CXCL8-induced FAK phosphorylation via CXCR1 and CXCR2: cytoskeleton- and integrinrelated mechanisms converge with FAK regulatory pathways in a receptorspecific manner. Cytokine 2006, 33:1-16.

48. Schraufstatter IU, Chung J, Burger M: IL-8 activates endothelial cell CXCR1 and CXCR2 through Rho and Rac signaling pathways. Am J Physiol Lung Cell Mol Physio/ 2001, 280:L1094-1103.

49. Britschgi A, Andraos R, Brinkhaus H, Klebba I, Romanet V, Muller U, Murakami M, Radimerski T, Bentires-Alj M: JAK2/STAT5 inhibition circumvents resistance to $\mathrm{PI} 3 \mathrm{~K} / \mathrm{mTOR}$ blockade: a rationale for cotargeting these pathways in metastatic breast cancer. Cancer Cell 2012, 22:796-811.

50. Seaton A, Scullin P, Maxwell PJ, Wilson C, Pettigrew J, Gallagher R, O'Sullivan JM, Johnston PG, Waugh DJ: Interleukin-8 signaling promotes androgenindependent proliferation of prostate cancer cells via induction of androgen receptor expression and activation. Carcinogenesis 2008, 29:1148-1156

51. Kitadai Y, Takahashi Y, Haruma K, Naka K, Sumii K, Yokozaki H, Yasui W, Mukaida N, Ohmoto Y, Kajiyama G, Fidler IJ, Tahara E: Transfection of interleukin-8 increases angiogenesis and tumorigenesis of human gastric carcinoma cells in nude mice. Br J Cancer 1999, 81:647-653.

52. Singh S, Sadanandam A, Nannuru KC, Varney ML, Mayer-Ezell R, Bond R, Singh RK: Small-molecule antagonists for CXCR2 and CXCR1 inhibit human melanoma growth by decreasing tumor cell proliferation, survival, and angiogenesis. Clin Cancer Res 2009, 15:2380-2386.

53. Zhu YM, Webster SJ, Flower D, Woll PJ: Interleukin-8/CXCL8 is a growth factor for human lung cancer cells. Br J Cancer 2004, 91:1970-1976.

54. Miller LJ, Kurtzman SH, Wang Y, Anderson KH, Lindquist RR, Kreutzer DL: Expression of interleukin-8 receptors on tumor cells and vascular endothelial cells in human breast cancer tissue. Anticancer Res 1998, 18:77-81.

55. Green AR, Green VL, White MC, Speirs V: Expression of cytokine messenger RNA in normal and neoplastic human breast tissue: identification of interleukin- 8 as a potential regulatory factor in breast tumours. Int $J$ Cancer 1997, 72:937-941.

56. Snoussi K, Mahfoudh W, Bouaouina N, Ahmed SB, Helal AN, Chouchane L: Genetic variation in IL-8 associated with increased risk and poor prognosis of breast carcinoma. Hum Immuno/ 2006, 67:13-21.

57. Snoussi K, Mahfoudh W, Bouaouina N, Fekih M, Khairi H, Helal A, Chouchane L: Combined effects of IL-8 and CXCR2 gene polymorphisms on breast cancer susceptibility and aggressiveness. BMC Cancer 2010, 10:283

58. De Larco JE, Wuertz BR, Rosner KA, Erickson SA, Gamache DE, Manivel JC, Furcht LT: A potential role for interleukin-8 in the metastatic phenotype of breast carcinoma cells. Am J Pathol 2001, 158:639-646.

59. Azenshtein E, Meshel T, Shina S, Barak N, Keydar I, Ben-Baruch A: The angiogenic factors CXCL8 and VEGF in breast cancer: regulation by an array of pro-malignancy factors. Cancer Letters 2005, 217:73-86.

60. Korkaya H, Kim Gl, Davis A, Malik F, Henry NL, Ithimakin S, Quraishi AA, Tawakko N, D'Angelo R, Paulson AK, Chung S, LutherT, Paholak HJ, Liu S, Hassan KA, Zen Q, Clouthier SG, Wicha MS: Activation of an IL6 inflammatory loop mediates trastuzumab resistance in HER2+ breast cancer by expanding the cancer stem cell population. Mol Cell 2012, 47:570-584.

61. Bohrer LR, Schwertfeger KL: Macrophages promote fibroblast growth factor receptor-driven tumor cell migration and invasion in a CXCR2-dependent manner. Mol Cancer Res 2012, 10:1294-1305.

62. Liu S, Ginestier C, Ou SJ, Clouthier SG, Patel SH, Monville F, Korkaya H, Heath A, Dutcher J, Kleer CG, Jung Y, Dontu G, Taichman R, Wicha MS: Breast cancer stem cells are regulated by mesenchymal stem cells through cytokine networks. Cancer Res 2011, 71:614-624.

63. Lin Y, Huang R, Chen L, Li S, Shi Q, Jordan C, Huang R-P: Identification of interleukin-8 as estrogen receptor-regulated factor involved in breast cancer invasion and angiogenesis by protein arrays. Int J Cancer 2004, 109:507-515.

64. Yao C, Lin Y, Chua M-S, Ye C-S, Bi J, Li W, Zhu Y-F, Wang S-M: Interleukin-8 modulates growth and invasiveness of estrogen receptor-negative breast cancer cells. Int J Cancer 2007, 121:1949-1957.

65. Bendre MS, Gaddy-Kurten D, Mon-Foote T, Akel NS, Skinner RA, Nicholas RW Suva L: Expression of interleukin 8 and not parathyroid hormone-related protein by human breast cancer cells correlates with bone metastasis in vivo. Cancer Res 2002, 62:5571-5579.

66. Bieche I, Chavey C, Andrieu C, Busson M, Vacher S, Le Corre L, Guinebretiere J-M, Burlinchon S, Lidereau R, Lazennec G: CXC chemokines located in the 4 q21 region are up-regulated in breast cancer. Endocrine-Related Cancer 2007, 14:1039-1052. 
67. Nannuru KC, Sharma B, Varney ML, Singh RK: Role of chemokine receptor CXCR2 expression in mammary tumor growth, angiogenesis and metastasis. J Carcinog 2012, 10:40.

68. Ginestier C, Liu S, Diebel ME, Korkaya H, Luo M, Brown M, Wicinski J, Cabaud O, Charafe-Jauffret E, Birnbaum D, Guan JL, Dontu G, Wicha MS: CXCR1 blockade selectively targets human breast cancer stem cells in vitro and in xenografts. J Clin Invest 2010, 120:485-497.

69. Derin D, Soydinc HO, Guney N, Tas F, Camlica H, Duranyildiz D, Yasasever V, Topuz E: Serum IL-8 and IL-12 levels in breast cancer. Med Oncol 2007, 24:163-168.

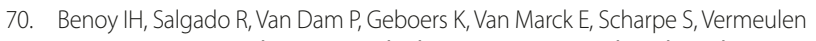
$P B$, Dirix LY: Increased serum interleukin-8 in patients with early and metastatic breast cancer correlates with early dissemination and survival. Clinical Cancer Res 2004, 10:7157-7162.

71. Shi Z, Yang WM, Chen LP, Yang DH, Zhou Q, Zhu J, Chen JJ, Huang RC, Chen ZS, Huang RP: Enhanced chemosensitization in multidrug-resistant human breast cancer cells by inhibition of IL- 6 and IL- 8 production. Breast Cancer Res Treat 2012, 135:737-747

72. De Larco JE, Wuertz BR, Manivel JC, Furcht LT: Progression and enhancement of metastatic potential after exposure of tumor cells to chemotherapeutic agents. Cancer Res 2001, 61:2857-2861.

73. Charafe-Jauffret E, Ginestier C, lovino F, Wicinski J, Cervera N, Finetti P, Hur MH, Diebel ME, Monville F, Dutcher J, Brown M, Viens P, Xerri L, Bertucci F, Stassi G, Dontu G, Birnbaum D, Wicha MS: Breast cancer cell lines contain functional cancer stem cells with metastatic capacity and a distinct molecular signature. Cancer Res 2009, 69:1302-1313.

74. Fernando RI, Castillo MD, Litzinger M, Hamilton DH, Palena C: IL-8 signaling plays a critical role in the epithelial-mesenchymal transition of human carcinoma cells. Cancer Res 2012, 71:5296-5306.

75. Mani SA, Guo W, Liao MJ, Eaton EN, Ayyanan A, Zhou AY, Brooks M, Reinhard F, Zhang CC, Shipitsin M, Campbell LL, Polyak K, Brisken C, Yang J, Weinberg RA: The epithelial-mesenchymal transition generates cells with properties of stem cells. Cell 2008, 133:704-715.

76. Hanahan D, Weinberg RA: Hallmarks of cancer: the next generation. Cell 2011, 144:646-674.

77. Morel AP, Lievre M, Thomas C, Hinkal G, Ansieau S, Puisieux A: Generation of breast cancer stem cells through epithelial-mesenchymal transition. PLOS One 2008, 3:e2888.

78. Singh JK, Farnie G, Bundred NJ, Simoes BM, Shergill A, Landberg G, Howell SJ, Clarke RB: Targeting CXCR1/2 Significantly Reduces Breast Cancer Stem Cell Activity and Increases the Efficacy of Inhibiting HER2 via HER2-Dependent and -Independent Mechanisms. Clin Cancer Res 2013, 19:643-656.

79. Li HJ, Reinhardt F, Herschman HR, Weinberg RA: Cancer-stimulated mesenchymal stem cells create a carcinoma stem cell niche via prostaglandin E2 signaling. Cancer Discov 2012, 2:840-855.

80. Hartman ZC, Poage GM, den Hollander P, Tsimelzon A, Hill J, Panupinthu N, Zhang Y, Mazumdar A, Hilsenbeck SG, Mills GB, Brown PH: Growth of triplenegative breast cancer cells relies upon coordinate autocrine expression of the proinflammatory cytokines IL-6 and IL-8. Cancer Res 2013, 73:3470-3480.

81. Slamon DJ, Clark GM, Wong SG, Levin WJ, Ullrich A, McGuire WL: Human breast cancer: correlation of relapse and survival with amplification of the HER-2/ neu oncogene. Science 1987, 235:177-182.

82. Korkaya H, Paulson A, lovino F, Wicha MS: HER2 regulates the mammary stem/ progenitor cell population driving tumorigenesis and invasion. Oncogene 2008, 27:6120-6130.

83. Magnifico A, Albano L, Campaner S, Delia D, Castiglioni F, Gasparini P, Sozzi G, Fontanella E, Menard S, Tagliabue E: Tumor-initiating cells of HER2-positive carcinoma cell lines express the highest oncoprotein levels and are sensitive to trastuzumab. Clin Cancer Res 2009, 15:2010-2021.

84. Hartman ZC, Yang XY, Glass O, Lei G, Osada T, Dave SS, Morse MA, Clay TM, Lyerly HK: HER2 overexpression elicits a proinflammatory IL-6 autocrine signaling loop that is critical for tumorigenesis. Cancer Res 2011, 71:4380-4391.

85. Wen XF, Yang G, Mao W, Thornton A, Liu J, Bast RC Jr., Le XF: HER2 signaling modulates the equilibrium between pro- and antiangiogenic factors via distinct pathways: implications for HER2-targeted antibody therapy. Oncogene 2006, 25:6986-6996.

86. Vazquez-Martin A, Colomer R, Menendez JA: Protein array technology to detect HER2 (erbB-2)-induced 'cytokine signature' in breast cancer. Eur J Cancer 2007, 43:1117-1124.

87. Aceto N, Duss S, Macdonald G, Meyer DS, Roloff TC, Hynes NE, Bentires-Alj M: Co-expression of HER2 and HER3 receptor tyrosine kinases enhances invasion of breast cells via stimulation of interleukin-8 autocrine secretion. Breast Cancer Res 2012, 14:R131.

88. Chavey C, Bibeau F, Gourgou-Bourgade S, Burlinchon S, Boissiere F, Laune D, Roques S, Lazennec G: Oestrogen receptor negative breast cancers exhibit high cytokine content. Breast Cancer Res 2007, 9:R15.

89. Korkaya H, Paulson A, Charafe-Jauffret E, Ginestier C, Brown M, Dutcher J, Clouthier SG, Wicha MS: Regulation of mammary stem/progenitor cells by PTEN/Akt/beta-catenin signaling. PLoS Bio/ 2009, 7:e1000121.

90. Aihara M, Tsuchimoto D, Takizawa H, Azuma A, Wakebe H, Ohmoto Y, Imagawa K, Kikuchi M, Mukaida N, Matsushima K: Mechanisms involved in Helicobacter pylori-induced interleukin-8 production by a gastric cancer cell line, MKN45. Infect Immun 1997, 65:3218-3224.

91. Stein B, Baldwin AS Jr.: Distinct mechanisms for regulation of the interleukin-8 gene involve synergism and cooperativity between C/EBP and NF-kappa B. Mol Cell Biol 1993, 13:7191-7198.

92. Mian BM, Dinney CP, Bermejo CE, Sweeney P, Tellez C, Yang XD, Gudas JM, McConkey DJ, Bar-Eli M: Fully human anti-interleukin 8 antibody inhibits tumor growth in orthotopic bladder cancer xenografts via down-regulation of matrix metalloproteases and nuclear factor-kappaB. Clin Cancer Res 2003, 9:3167-3175.

93. Huang S, Mills L, Mian B, Tellez C, McCarty M, Yang XD, Gudas JM, Bar-Eli M: Fully humanized neutralizing antibodies to interleukin-8 (ABX-IL8) inhibit angiogenesis, tumor growth, and metastasis of human melanoma. Am J Pathol 2002, 161:125-134.

94. Skov L, Beurskens FJ, Zachariae CO, Reitamo S, Teeling J, Satijn D, Knudsen KM, Boot EP, Hudson D, Baadsgaard O, Parren PW, van de Winkel JG: IL-8 as antibody therapeutic target in inflammatory diseases: reduction of clinical activity in palmoplantar pustulosis. J Immuno/ 2008, 181:669-679.

95. Ning Y, Labonte MJ, Zhang W, Bohanes PO, Gerger A, Yang D, Benhaim L, Paez D, Rosenberg DO, Nagulapalli Venkata KC, Louie SG, Petasis NA, Ladner RD, Lenz HJ: The CXCR2 antagonist, SCH-527123, shows antitumor activity and sensitizes cells to oxaliplatin in preclinical colon cancer models. Mol Cancer Ther 2012, 11:1353-1364.

96. Varney ML, Singh S, Li A, Mayer-Ezell R, Bond R, Singh RK: Small molecule antagonists for CXCR2 and CXCR1 inhibit human colon cancer liver metastases. Cancer Lett 2011, 300:180-188.

97. Hirose K, Hakozaki M, Nyunoya Y, Kobayashi Y, Matsushita K, Takenouchi T, Mikata A, Mukaida N, Matsushima K: Chemokine gene transfection into tumour cells reduced tumorigenicity in nude mice in association with neutrophilic infiltration. Br J Cancer 1995, 72:708-714.

98. Teng MW, Swann JB, Koebel CM, Schreiber RD, Smyth MJ: Immune-mediated dormancy: an equilibrium with cancer. J Leukoc Bio/ 2008, 84:988-993.

99. Nair P, Gaga M, Zervas E, Alagha K, Hargreave FE, O'Byrne PM, Stryszak P, Gann L, Sadeh J, Chanez P: Safety and efficacy of a CXCR2 antagonist in patients with severe asthma and sputum neutrophils: a randomized, placebo-controlled clinical trial. Clin Exp Allergy 2012, 42:1097-1103.

100. Bertini R, Allegretti M, Bizzarri C, Moriconi A, Locati M, Zampella G, Cervellera MN, Di Cioccio V, Cesta MC, Galliera E, Martinez FO, Di Bitondo R, Troiani G, Sabbatini V, D'Anniballe G, Anacardio R, Cutrin JC, Cavalieri B, Mainiero F, Strippoli R, Villa P, Di Girolamo M, Martin F, Gentile M, Santoni A, Corda D, Poli G, Mantovani A, Ghezzi P, Colotta F: Noncompetitive allosteric inhibitors of the inflammatory chemokine receptors CXCR1 and CXCR2: prevention of reperfusion injury. Proc Natl Acad SciU S A 2004, 101:11791-11796.

101. Leitner JM, Mayr FB, Firbas C, Spiel AO, Steinlechner B, Novellini R, Jilma B: Reparixin, a specific interleukin-8 inhibitor, has no effects on inflammation during endotoxemia. Int J Immunopathol Pharmacol 2007, 20:25-36.

102. Korkaya H, Liu S, Wicha MS: Breast cancer stem cells, cytokine networks, and the tumor microenvironment. J Clin Invest 2011, 121:3804-3809.

103. Korkaya H, Wicha MS: Breast cancer stem cells: we've got them surrounded. Clin Cancer Res 2013, 19:511-513.

104. Schott A, Wicha M, Cristofanilli M, Ruffini P, McCanna S, Reuben J, Goldstein L: Phase Ib pilot study to evaluate reparixin in combination with chemotherapy with weekly paclitaxel in patients with HER-2 negative metastatic breast cancer (MBC) [Abstract]. Cancer Res 2012, 72 (24 Suppl):571s.

\section{doi:10.1186/bcr3436}

Cite this article as: Singh JK, et al:: Recent advances reveal IL-8 signaling as a potential key to targeting breast cancer stem cells. Breast Cancer Research 2013, 15:210. 